\title{
In Vitro Corrosion and Bioactivity Study of Surface Phytic Acid Modified AZ31 Magnesium Alloy
}

\author{
Xu Yang ${ }^{1 *}$, Lanlan $\mathrm{Li}^{1}$, Jian $\mathrm{He}^{1}$, Haiying Guo ${ }^{2}$, Jiqiang Zhang ${ }^{3}$ \\ ${ }^{1}$ Department of Chemistry, Third Military Medical University, Chongqing, China; ${ }^{2}$ Department of Cell Biology, Third Military \\ Medical University, Chongqing, China; ${ }^{3}$ Department of Neurobiology, Third Military Medical University, Chongqing, China.

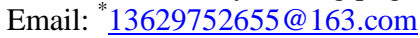

Received November $22^{\text {nd }}$, 2013; revised December $30^{\text {th }}$, 2013; accepted January $13^{\text {th }}, 2014$

Copyright (C 2014 Xu Yang et al. This is an open access article distributed under the Creative Commons Attribution License, which permits unrestricted use, distribution, and reproduction in any medium, provided the original work is properly cited. In accordance of the Creative Commons Attribution License all Copyrights (c) 2014 are reserved for SCIRP and the owner of the intellectual property Xu Yang et al. All Copyright (C) 2014 are guarded by law and by SCIRP as a guardian.

\section{ABSTRACT}

The purpose of the present work was to examine in vitro corrosion and bioactivity of surface phytic acid treatment AZ31 magnesium alloys. Untreated AZ31 magnesium alloys were used as control. The surface morphologies of magnesium alloys were observed by SEM. EDS was used to analyze the surface chemical elemental compositions and elemental concentration distribution. Corrosion properties were evaluated by electrochemical tests. Human osteosarcoma MG-63 cells were used to examine cell viability and proliferation. The results showed that surface phytic acid treatment resulted in a surface coating formation, which did not significantly improve the corrosion resistance of the alloys. The corrosion potential of AZ31 magnesium alloy positive shifted only about $0.04 \mathrm{~V}$ (from $-1.50 \mathrm{~V}$ to $-1.46 \mathrm{~V}$ ); and the corrosion current decreased only $0.354 \mathrm{~mA} / \mathrm{cm}^{2}\left(\right.$ from $2.547 \times 10^{-3}$ $\mathrm{mA} / \mathrm{cm}^{2}$ to $2.193 \times 10^{-3} \mathrm{~mA} / \mathrm{cm}^{2}$ ). However, the cell analysis showed that this coating induced obviously higher MG-63 cell viability and proliferation, and displayed good surface bioactivity.

\section{KEYWORDS}

\section{AZ31 Magnesium Alloy; Phytic Acid; Surface Coating; Corrosion; Bioactivity}

\section{Introduction}

Magnesium alloys have attracted much attention because of their potential biodegradable bone implant applications due to their excellent mechanical properties and biodegradability in the bio-environment [1-5]. A substantial amount of $\mathrm{Mg}$ is taken into the human body daily and is beneficial for bone strength and growth. The physical and mechanical properties of $\mathrm{Mg}$ are close to those of bone. No secondary surgery is needed when the bone tissue is healed because the $\mathrm{Mg}$ implant is biodegradable and absorbable [6-9]. So, in orthopedic and bone replacement applications, $\mathrm{Mg} / \mathrm{Mg}$ alloys have advantages over any other metallic or polymer implants. However, the rapid corrosion of magnesium alloys in aggressive physiological in vivo environment may result in that magnesium implants cannot maintain sufficient

\footnotetext{
${ }^{*}$ Corresponding author.
}

mechanical integrity before the tissue has sufficiently healed, which has limited their clinical applications.

An ideal degradable biomaterial for bone regeneration is expected to be not only degradation controllable but also bioactive [6]. In general, as an implant material, only its surface contacts with the host tissue directly, thus this portion of the material plays a central role in determining its degradation resistance, biocompatibility and bioactivity [10]. The surface modifying methods are attractive technologies in gaining suitable coatings to improve magnesium implant bioactivity and protect it from fast in vivo corrosion and degradation [11-13]. Of all surface coatings, the calcium-phosphate coating is one of major coatings that have been studied extensively for modifying the surface of implanted devices, and have been successfully applied to the surface modification of $\mathrm{Ti}$ and its alloys in order to promote direct attachment of the surrounding hard tissue and to suppress the release of 
corrosion products into the human body [14]. At the same time, the compounds containing calcium and phosphate have also been studied to use for the formation of bioactive coatings and or for inhibiting magnesium alloys fast corrosion [15-19].

In recent years, an organic molecule, which is phytic acid (PA), is gaining increased interest because of the similarity in composition to phosphate and good biocompatibility [20]. The previous works have been reported about the application of PA conversion coating or corrosion resistant inhibitor for the paint or pigment systems on magnesium alloys [21-23]. But rare works reported the bioactivity of PA conversion coating on the magnesium alloys.

In this study, AZ31 magnesium alloy was modified with PA solution through immersion method, which is expected to prepare the PA coating on magnesium alloy and improve the surface corrosion resistance as well as the surface bioactivity. The in vitro corrosion properties of the AZ31 magnesium alloys with PA coatings were evaluated by electrochemical corrosion tests, the in vitro biocompatibility and the surface bioactivity were assessed by short-term tests using the human osteosarcoma MG-63.

\section{Materials and Methods}

\subsection{Sample Preparation}

Commercial AZ31 magnesium alloys were provided by the National Engineering Research Center for Magnesium Alloy of Chongqing University. For the PA modification, plate samples with a dimension of $10 \mathrm{~mm}$ in diameter and $3 \mathrm{~mm}$ in thickness were cut from the magnesium alloy bars, all samples were mechanically polished by polishing machine (UNIPOL-800, Sheng yang Kejing Instrument Co. Ltd.) with sand paper no.1000, then ultrasonically washed in acetone for $10 \mathrm{~min}$, followed by washing with absolute ethanol and distilled water in turn, finally dried with warm air.

Surface modification of magnesium alloys was carried out in PA solution. The samples were immersed in a 15 $\mathrm{mg} / \mathrm{ml}$ PA solution (pH 6.0) for $10 \mathrm{~min}$ in order to obtain a PA surface coating. The PA solutions were prepared by dissolving PA (purity $>70 \%$, purchased from Chongqing Medicines Co. Ltd.), the $\mathrm{pH}$ value of the solution was adjusted by adding sodium hydroxide solution (prepared by analytical grade sodium hydroxide and distilled water) as our previous report [22]. After immersion, the samples were thoroughly washed using running distilled water, dried in warm air.

\subsection{Surface Morphologies Observation}

The surface morphologies of magnesium alloys treated with PA solutions were observed using scanning electron microscopy (S-3400N, Hitachi, Japan). Energy dispersive X-ray spectroscopy (EDS, Thermo Electron Corporation) was used to analyze the chemical composition of the treated magnesium alloy surface. The relative quantification was done by fixing the acceleration voltages and data acquisition conditions.

\subsection{In Vitro Corrosion Test}

To evaluate the effect for corrosion property of magnesium alloys through PA treatment, the potentiodynamic polarization measurement in Hank's solution was carried out to comparatively investigate the corrosion behavior of the bare alloy to the alloy with the surface coating. A three-electrode cell was used for electrochemical measurements. The counter electrode was made of platinum and the reference electrode was saturated calomel electrode (SCE). The exposed area of the working electrode (treated or untreated AZ31 magnesium alloy samples with PA solutions) to the solution was $0.785 \mathrm{~cm}^{2}$. All the measurements were carried out on an electro-chemical workstation (CS2350, CorrTest, China) at the temperature of $25^{\circ} \mathrm{C}$. The test milieu was Hank's solution.

\subsection{Cell Culture and Proliferative Analysis}

Biocompatibility of the PA modified AZ31 was examined using immature osteoblast-like cell line MG-63 which was purchased from Shanghai Institute of Biochemistry and Cell Biology (Shanghai, China). The osteoblasts were cultured in Dulbecco' s modified Eagle's medium (DMEM) (Invitrogen Life Tech., Shanghai, China) containing $10 \%$ fetal bovine serum (Sigma), $1 \%$ PSF $(100 \times$, 10,000 U/ml Penicillin, 10,000 mg/ml Streptomycin and $25 \mathrm{mg} / \mathrm{ml}$ Fungizones) (Invitrogen Life Tech., Shanghai, China) under a humidified $5 \% \mathrm{CO}_{2}$ air atmosphere at $37^{\circ} \mathrm{C}$. Cells were seeded on the top surface of each metal material (placed in a 24-well-plate) at a concentration of 10,000 cells/well.

A MTT test kit (C0009; Beyondtime, China) was used for cell proliferation analysis. The protocol was as the followings: PA modified or unmodified AZ31 were placed on the bottom of the wells of 24-well plates (3 well for each treatment), and cells were plated on the modified surface and cultured for $48 \mathrm{~h}$, then 10ul MTT solution was added to each well and cultured for another $4 \mathrm{~h}$, followed by $100 \mathrm{ul}$ Formanzan per well and the cells were incubated at $37^{\circ} \mathrm{C}$ for $4 \mathrm{~h}$. The medium was removed and dimethyl sulfoxide (DMSO) was added to dissolve the formazan crystals. Finally, 200 ul solution from each well was transferred to 96-well plate and the absorbance was measured at $570 \mathrm{~nm}$ with a common ELISA reader.

Cell visualization was carried out by the following as the previous report [24] with slight modifications. The 
metal materials were washed with PBS (phosphate buffered saline, $10 \mathrm{mmol} / \mathrm{L} ; \mathrm{pH} 7.4$ ), and blocked in $2 \%$ normal goat serum for $30 \mathrm{~min}$ at room temperature. Then incubated over night at $4^{\circ} \mathrm{C}$ with the $\alpha$-Tubulin primary polyclonal antiserum (sc-5546, Santa Cruz, USA) diluted 1:200 with Antibody Diluent (S3022, Dako Inc., Glostrup, Denmark). After several washes with PBS, the metal materials were incubated with AlexaFluor $568^{\circledR}$ goat anti-rabbit IgG (1:600; A-11011, USA) for $1 \mathrm{~h}$, and counterstained with Dapi (H1200, Molecular Probes; USA) then examined under Olympus microscope (BX60, Japan).

Data of MTT analysis were showed as mean \pm S.E., then analyzed with SPSS software (version 13.0; IBM, Chicago, IL) and $\chi^{2}$ was employed to compare the differences between modified and unmodified materials, a level of $p<0.05$ was considered to be statistical significant.

\section{Results}

\subsection{Microstructure of Surface Treatment Magnesium Alloy}

The surface morphology and the EDS result of AZ31 magnesium alloy treated with PA solution were shown in Figure 1. Compared to the untreated AZ31 magnesium alloy, there was an obvious conversion coating formed on the treated magnesium alloy surface, its result of surface EDS analysis (as shown in Figure 1(a1)) indicated that the chemical elemental compositions were mainly $\mathrm{Mg}, \mathrm{Al}, \mathrm{P}, \mathrm{C}, \mathrm{O}$ and a small amount of $\mathrm{Zn}$. The corresponding elemental compositions (Figure 1(b1)) of untreated AZ31 magnesium alloy were only $\mathrm{Mg}, \mathrm{Al}$, and Zn.

\subsection{Corrosion Resistance of Treated Magnesium Alloys}

The electrochemical polarization curves of the PA treatment AZ31 magnesium alloys in Hank's solution were shown in Figure 2. The bare AZ31 magnesium alloy was set as control. As seen from Figure 2, the corrosion potential of the bare alloy was about $-1.50 \mathrm{~V}$. In contrast, the corrosion potential of treated magnesium alloy was a little positive, shifting to about $-1.46 \mathrm{~V}$. It was noted that the corrosion current density of the treated magnesium alloy was $2.193 \times 10^{-3} \mathrm{~mA} / \mathrm{cm}^{2}$, a little decrease than that of untreated alloy $\left(2.547 \times 10^{-3} \mathrm{~mA} / \mathrm{cm}^{2}\right)$. The results were summarized in Table 1.

\subsection{Cell Viability/Proliferation}

$\alpha$-Tubulin immunocytochemistry was used to visualize the cytoskeleton and Dapi was used to visualize the nuclei of MG-63 cells, the results showed that MG-63 cells
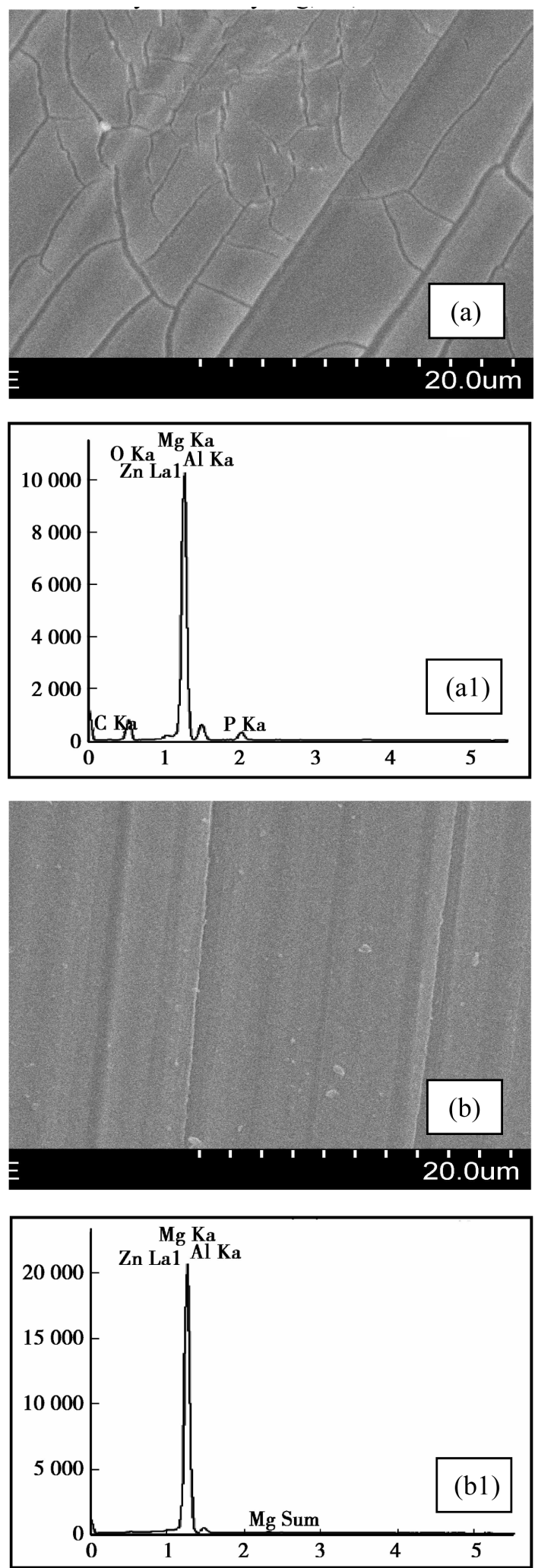

Figure 1. Microstructure of AZ31 magnesium alloys with or without surface treatment: (1) SEM surface micrograph of treated (a) and untreated (b) magnesium alloys. (2) The result of EDS analysis on treated (a1) and untreated (b1) magnesium alloy surface. 


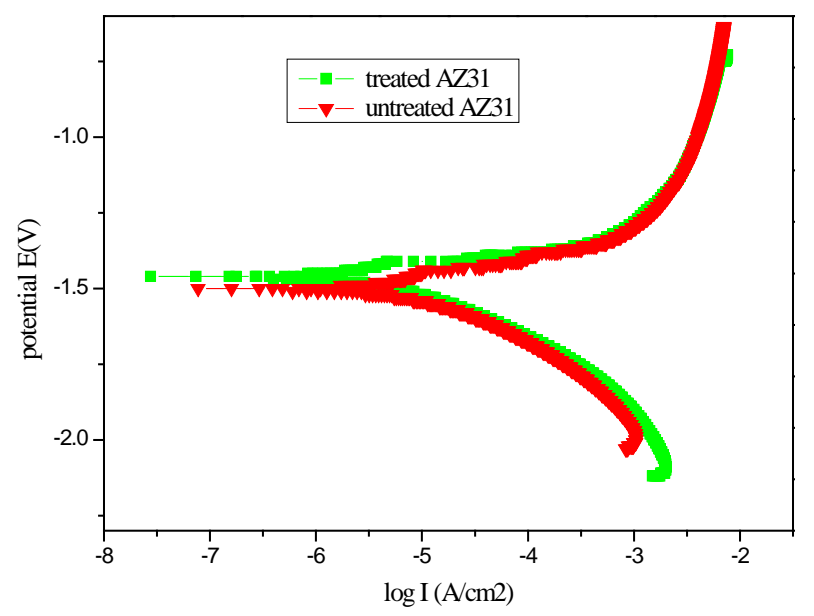

Figure 2. Potentiodynamic polarization curves of the PA treatment AZ31 magnesium alloys and the bare AZ31 control sample in Hank's solution.

Table 1. Fitting results of polarization curves.

\begin{tabular}{ccc}
\hline samples & $\begin{array}{c}\text { Corrosion potential } \\
\left(\mathrm{E}_{\text {corro }}(\mathrm{V})\right)\end{array}$ & $\begin{array}{c}\text { Corrosion current density } \\
\left(i_{\text {corro }}\left(\mathrm{mA} / \mathrm{cm}^{2}\right)\right)\end{array}$ \\
\hline Untrated AZ31 & -1.50 & $2.547 \times 10^{-3}$ \\
Treated AZ31 & -1.46 & $2.193 \times 10^{-3}$ \\
\hline
\end{tabular}

grew well on the metal surface as shown in Figure 3, either treated or untreated by phytic acid. The classic MTT analysis was employed to test the potential cytotoxicity of PA on the proliferation of MG-63 cells, the results revealed that cell proliferation was dramatically induced by PA modification when compared to the unmodified controls as shown in Figure 4.

\section{Discussion}

\subsection{The Surface Coating and Corrosion Behavior}

The Figure 1(a) showed that the coating layer was formed, and the EDS analysis (Figure 1(a1)) result indicated that the chemical elemental compositions of the coatings were mainly $\mathrm{Mg}$ and a small amount of $\mathrm{Al}, \mathrm{P}, \mathrm{C}$, $\mathrm{O}$, Zn. It is well known that PA $\left(\mathrm{C}_{6} \mathrm{H}_{18} \mathrm{O}_{24} \mathrm{P}_{6}\right)$ consists of 24 oxygen atoms, 12 hydroxyl groups and 6 phosphate carboxyl groups [25-27]. It could deprotonate according to the equilibrium (1) (the completely deprotonated form is denoted in this work by $\left.\mathrm{Phy}^{12-}\right)$ :

$$
\mathrm{H}_{\mathrm{i}} \mathrm{Phy}^{(12-\mathrm{i})-} \leftrightharpoons \mathrm{H}^{+}+\mathrm{H}_{(\mathrm{i}-1)} \text { Phy }^{(12-\mathrm{i}+1)-}(\mathrm{i}=12,11, \cdots, 1)(1)
$$

Due to its high density of negatively charged phosphate groups, PA, in its various deprotonated forms, has the ability to bind or chelate multivalent cations by coordinate bonds through reaction with paired oxo-dianions of the phosphoryl groups [25]. So, compared to the control (Figure 1(b1)), the three EDS signals of carbon,

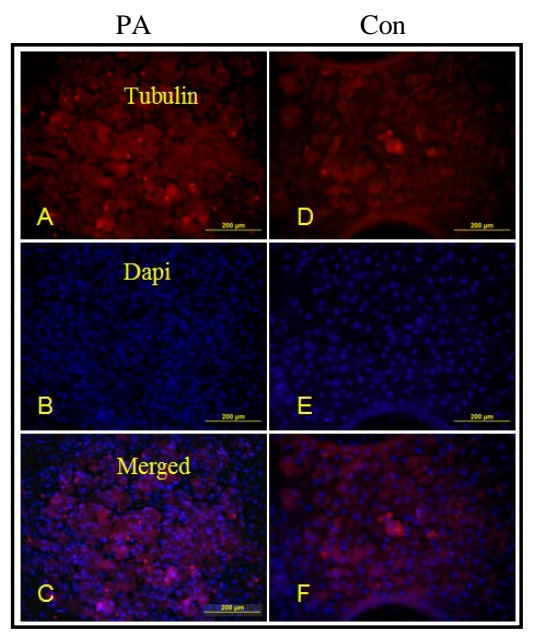

Figure 3 . The results of the cytoskeleton and the nuclei of MG-63 cells on modified magnesium alloys ((A)-(C)) and the bare magnesium alloys ((D)-(E)).

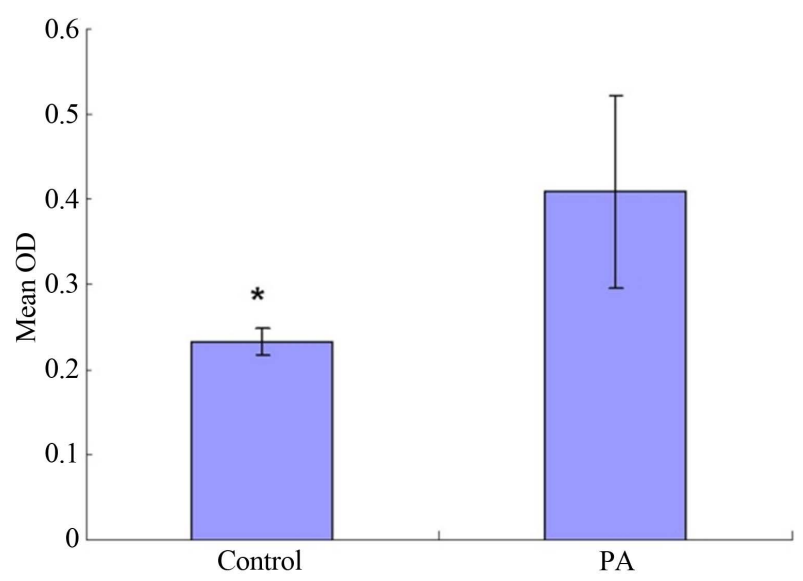

Figure 4. The results of the proliferation of MG-63 cells on PA modification magnesium alloys and the unmodified controls in MTT test.

oxygen and phosphorus suggested the presence of PA on the surface of AZ31 magnesium alloys. In other words, the PA conversion coating formed on the surface by chelating of metal cations (such as $\mathrm{Al}^{3+}, \mathrm{Zn}^{2+}$ and $\mathrm{Mg}^{2+}$ ) with $\mathrm{PA}$ and formation insoluble complexes [22,25].

Figure 2 presented the potentiodynamic polarization curves for the treated specimen and untreated control specimen. Compared with that of the control, the corrosion potential Ecorr was shifted positively about $0.04 \mathrm{~V}$ from $-1.46 \mathrm{~V}$ to $-1.50 \mathrm{~V}$, and the corrosion current density $i_{\text {corr }}$ decreased from $2.193 \times 10^{-3} \mathrm{~mA} / \mathrm{cm}^{2}$ to $2.547 \times$ $10^{-3} \mathrm{~mA} / \mathrm{cm}^{2}$. Thus, after the PA treatment, the corrosion resistance of AZ31 magnesium alloy was slightly improved, the magnesium alloy also remained in an active state and further protection was necessary to prevent corrosion.

In aforementioned sections, the formed PA conversion coating showed a limited improvement to the corrosion 
resistance of AZ31 magnesium alloy. This finiteness may be explained by the nature of coating formation. According previous studies, $\mathrm{Mg}, \mathrm{Zn}$ and $\mathrm{Al}$ atoms of the AZ31 magnesium alloy surface were oxidized into $\mathrm{Mg}^{2+}$, $\mathrm{Zn}^{2+}$ and $\mathrm{Al}^{3+}$ in acidic solution, then reversibly chelated with PA into different complexes (showed by $\mathrm{MH}_{(\mathrm{i}-\mathrm{n})} \mathrm{Phy}$, $\mathrm{M}$ is $\mathrm{Mg}^{2+}, \mathrm{Zn}^{2+}$ or $\mathrm{Al}^{3+}$ ) and deposited on the surface. All the complexes have the similar structure with phosphate [22,25,27], but there are different chemical composition and properties $[25,27]$. $\mathrm{AlH}_{(\mathrm{i}-3)}$ Phy compound has the higher stability and the lower solubility than those of other compounds $\mathrm{ZnH}_{(\mathrm{i}-2)}$ Phy and $\mathrm{MgH}_{(\mathrm{i}-2)}$ Phy [25]. It is right the stability and solubility difference of compounds $\left(\mathrm{MH}_{(\mathrm{i}-\mathrm{n})} \mathrm{Phy}\right)$ as well as the amount difference of metals in alloy that result in heterogeneity of the PA coating, and affect the corrosion resistance further improvement. A schematic diagram (shown in Figure 5) may be a better description.

\subsection{The Biocompatibility and Bioactivity of Surface Coating}

The cytoskeleton and the nuclei of MG-63 cells visua-

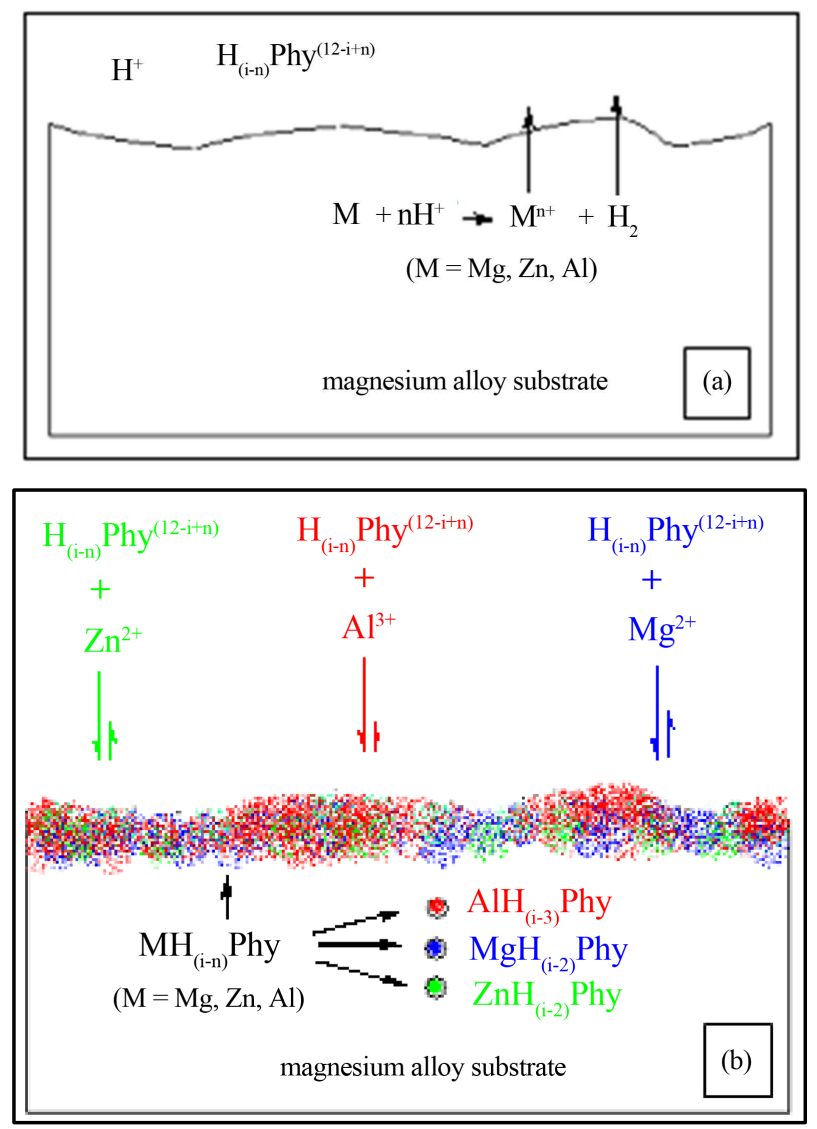

Figure 5. Schematic illustration of formation PA coating on magnesium alloy surface: (a) the reaction between substrate and PA; (b) the formation and deposition of complexes $\left(\mathrm{MH}_{(\mathrm{i}-\mathrm{n})}\right.$ Phy, $\mathrm{M}$ is $\mathrm{Mg}^{2+}, \mathrm{Zn}^{2+}$ or $\left.\mathrm{Al}^{3+}\right)$. lized by $\alpha$-Tubulin immunocytochemistry and Dapi staining showed that MG-63 cells grew well on the metal surface (Figure 3) either treated or untreated by phytic acid. On the other hand, the results of the classic MTT analysis revealed that cell proliferation was dramatically induced by PA modification when compared to the unmodified controls (Figure 4).

For biomaterials application, the surface bioactivity is mainly controlled by the surface properties. The chemical properties of the biomaterials play a very important role in good surface bioactivity. In order to improve the surface biocompatibility, various calcium phosphate coatings including octacalcium phosphate and hydroxyapatite have been successfully applied to magnesium alloys [28], because these compounds contain the same chemical composition or structure as the mineral composition of natural bone and the release of $\mathrm{Ca}^{2+}$ and $\mathrm{PO}_{4}{ }^{3}$ during hydrolysis which can be utilized in the course of forming new bone [29]. The previous studies have indicated that the formation of PA conversion coating on AZ magnesium alloy surface is due to the chelating of $\mathrm{Mg}^{2+}$, $\mathrm{Zn}^{2+}$ and $\mathrm{Al}^{3+}$ with PA by coordinate bonds and deposition $[21,22,25]$. At the same time, the conversion coating may also slowly release metal ions (such as $\mathrm{Mg}^{2+}, \mathrm{Zn}^{2+}$ etc.) by reversibly $[21,25] . \mathrm{Mg}^{2+}$ is known to be active in cell adhesion mechanisms, and it is necessary for calcium incorporation [29]. It has already shown that $\mathrm{Mg}^{2+}$ substituted tricalcium phosphate could stimulate cell proliferation and the synthesis and secretion of collagenase $[30,31] . \mathrm{Zn}^{2+}$ also plays important roles in controlling the function of osteoblasts and increasing osteoblast adhesion and the alkaline phosphatase activity of bone cells [5]. The cytocompatibility of calcium phosphate/collagen composites doped with $\mathrm{Zn}^{2+}$ is acceptable and the composites can be considered as a promising biomaterial that has the potentials of promoting bone formation [29,32]. In addition, $\mathrm{Zn}^{2+}$ and $\mathrm{Mg}^{2+}$ in the coating may promote osteogenesis due to their stimulatory effects on osteoblastic cell proliferation and bone formation [33,34]. It has been reported that osteoblast-like MG63 cells are attached to and spread completely on a calcium zinc magnesium phosphate (CaZnMgP) matrix and this matrix appears to be comparable to the control group (hydroxyapatite matrix) [35,36]. Therefore, divalent cations such as $\mathrm{Ca}^{2+}, \mathrm{Zn}^{2+}$ and $\mathrm{Mg}^{2+}$ in the Ca-P layer also promote cell growth and differentiation [35-37]. According to our previous study, the PA coatings on AZ magnesium alloys surface have the similar chemical composition or structure with various phosphates, hydroxyapatite, and the natural bone. Hence, it could be speculated that it is such a similar structure that promote cell growth and proliferation, this similar chemical composition or structure may be the nature of the biological activity caused by PA treatment AZ31 magnesium alloys. 


\section{Conclusion}

In this study, the surface PA coating was successfully prepared on AZ31 magnesium alloy by immersion modification method. But the corrosion resistance of AZ31 alloy was not significantly improved by PA modification. Its corrosion potential positive shifted only about $0.04 \mathrm{~V}$ (from $-1.50 \mathrm{~V}$ to $-1.46 \mathrm{~V}$ ), and the corrosion current decreased also only $0.354 \mathrm{~mA} / \mathrm{cm}^{2}$ (from $2.547 \times 10^{-3}$ $\mathrm{mA} / \mathrm{cm}^{2}$ to $2.193 \times 10^{-3} \mathrm{~mA} / \mathrm{cm}^{2}$ ). However, the coating exhibited similar chemical composition or structure to that of various phosphates, hydroxyapatite and the natural bone. It could promote cell growth and proliferation; improve the surface bioactivity of magnesium alloy significantly, which provided a novel alternative for speeding up the early bone response synchronously to magnesium alloys implants.

\section{Acknowledgements}

The authors acknowledge the financial support provided by the Scientific and Technological Research Project of CQ CSTC (No. 2010AB5116).

\section{REFERENCES}

[1] F. Witte, V. Kaese, H. Haferkamp, E. Switzer, A. MeyerLindenberg, C. J. Wirth and H. Windhagen, "In Vivo corrosion of Four Magnesium Alloys and the Associated Bone Response,” Biomaterials, Vol. 26, No. 17, 2005, pp. 3557-3563. http://dx.doi.org/10.1016/j.biomaterials.2004.09.049

[2] L. P. Xu, G. N. Yu, E. Zhang, F. Pan and K. Yang, "In Vivo Corrosion Behavior of Mg-Mn-Zn Alloy for Bone Implant Application,” Journal of Biomedical Materials Research Part A, Vol. 83A, No. 3, 2007, pp. 703-711. http://dx.doi.org/10.1002/jbm.a.31273

[3] F. Witte, J. Fischer, J. Nellesen, H. A. Crostack, V. Kaese, A. Pisch, F. Beckmann and H. Windhagen, "In Vitro and in Vivo Corrosion Measurements of Magnesium Alloys," Biomaterials, Vol. 27, No. 7, 2006, pp. 1013-1018. http://dx.doi.org/10.1016/j.biomaterials.2005.07.037

[4] Y. Xin, T. Hu and P. K. Chu, "In Vitro Studies of Biomedical Magnesium Alloys in a Simulated Physiological Environment: A Review,” Acta Biomater, Vol. 7, No. 4, 2011, pp. 1452-1459. http://dx.doi.org/10.1016/j.biomaterials.2005.07.037

[5] X. N. Gu, Y. F. Zheng, Y. Cheng, S. P. Zhong and T. F. $\mathrm{Xi}$, "In Vitro Corrosion and Biocompatibility of Binary Magnesium Alloys,” Biomaterials, Vol. 30, No. 4, 2009, pp. 484-498. http://dx.doi.org/10.1016/j.biomaterials.2008.10.021

[6] M. P. Staiger, A. M. Pietak, J. Huadmai and G. Dias, "Magnesium and Its Alloys as Orthopedic Biomaterials: A Review,” Biomaterials, Vol. 27, No. 9, 2006, pp. 17281734. http://dx.doi.org/10.1016/j.biomaterials.2005.10.003

[7] G. L. Song, "Control of Biodegradation of Biocompatable
Magnesium Alloys,” Corrosion Science, Vol. 49, No. 4, 2007, pp. 1696-1701.

http://dx.doi.org/10.1016/j.corsci.2007.01.001

[8] L. P. Xu, E. L. Zhang, D. S. Yin, S. Y. Zeng and K. Yang, "In Vitro Corrosion Behaviour of Mg Alloys in a Phosphate Buffered Solution for Bone Implant Application,” Journal of Materials Science: Materials in Medicine, Vol. 19, No. 3, 2008, pp. 1017-1025. http://dx.doi.org/10.1007/s10856-007-3219-y

[9] D. S. Yin, E. L. Zhang and S. Y. Zeng, "Effect of Zn on Mechanical Property and Corrosion Property of Extruded Mg-Zn-Mn Alloy,” Transactions of Nonferrous Metals Society, Vol. 18, No. 4, 2008, pp. 763-768. http://dx.doi.org/10.1016/S1003-6326(08)60131-4

[10] E. Willbold and F. Witte, "Histology and Research at the Hard Tissue-Implant Interface Using Technovit 9100 New Embedding Technique,” Acta Biomaterialia, Vol. 6, No. 11, 2010, pp. 4447-4455. http://dx.doi.org/10.1016/j.actbio.2010.06.022

[11] G. D. Zhang, J. J. Huang, K. Yang, B. C. Zhang and H. J. $\mathrm{Ai}$, "Experimental Study of in Vivo Implantation of a Magnesium Alloy at Early Stage,” Acta Metallurgica Sinica, Vol. 43, No. 11, 2007, pp. 1186-1190.

[12] L. H. Chiu, C. C. Chen and C. F. Yang, "Improvement of Corrosion Properties in an Aluminum-Sprayed AZ31 Magnesium Alloy by a Post-Hot Pressing and Anodizincy Treatment," Surface and Coatings Technology, Vol. 191, No. 2-3, 2005, pp. 181-187. http://dx.doi.org/10.1016/j.surfcoat.2004.02.035

[13] H. Hornberger, S. Virtanen and A. R. Boccaccini, "Biomedical Coatings on Magnesium Alloys-A Review," Acta Biomaterialia, Vol. 8, No. 7, 2012, pp. 2442-2455. http://dx.doi.org/10.1016/j.actbio.2012.04.012

[14] C. Y. Zheng, S. J. Li, X. J. Tao, Y. L. Hao, R. Yang and L. Zhang, "Calcium Phosphate Coating of Ti-Nb-Zr-Sn Titanium Alloy,” Materials Science and Engineering: C, Vol. 27, No. 4, 2007, pp. 824-831. http://dx.doi.org/10.1016/j.msec.2006.09.021

[15] L. P. Xu, F. Pan, G. N. Yu, L. Yang, E. L. Zhang and K. Yang, "In Vitro and in Vivo Evaluation of the Surface Bioactivity of a Calcium Phosphate Coated Magnesium Alloy,” Biomaterials, Vol. 30, No. 8, 2009, pp. 15121523. http://dx.doi.org/10.1016/j.biomaterials.2008.12.001

[16] S. Hiromoto and A. Yamamoto, "High Corrosion Resistance of Magnesium Coated with Hydroxyapatite Directly Synthesized in an Aqueous Solution,” Electrochimica Acta, Vol. 54, No. 27, 2009, pp. 7085-7093. http://dx.doi.org/10.1016/j.electacta.2009.07.033

[17] X. F. Cui, Y. Y. Yang, E. B. Liu, G. Jin, J. G. Zhong and Q. F. Li, "Corrosion Behaviors in Physiological Solution of Cerium Conversion Coatings on AZ31 Magnesium Alloy,” Applied Surface Science, Vol. 257, No. 23, 2011, pp. 9703-9709.

http://dx.doi.org/10.1016/j.apsusc.2011.04.141

[18] L. P. Xu, E. L. Zhang and K. Yang, "Phosphating Treatment and Corrosion Properties of Mg-Mn-Zn Alloy for Biomedical Application,” Journal of Materials Science: Materials in Medicine, Vol. 20, No. 4, 2009, pp. 859-867. 
http://dx.doi.org/10.1007/s10856-008-3648-2

[19] Y. W. Song, D. Y. Shan and E. H. Han, "Electrodeposition of Hydroxyapatite Coating on AZ91D Magnesium Alloy for Biomaterial Application,” Materials Letters, Vol. 62, No. 17-18, 2008, pp. 3276-3279. http://dx.doi.org/10.1016/j.matlet.2008.02.048

[20] K. Dost and O. Tokul, "Determination of Phytic Acid in Wheat and Wheat Products by Reverse Phase High Performance Liquid Chromatography," Analytica Chimica Acta, Vol. 558, No. 1-2, 2006, pp. 22-27. http://dx.doi.org/10.1016/j.aca.2005.11.035

[21] X. F. Cui, Y. Li, Q. F. Li, G. Jin, M. H. Ding and F. H. Wang, "Influence of Phytic Acid Concentration on Performance of Phytic Acid Conversion Coatings on the AZ91D Magnesium Alloy,” Materials Chemistry and Physics, Vol. 111, No. 2-3, 2008, pp. 503-507. http://dx.doi.org/10.1016/j.matchemphys.2008.05.009

[22] F. S. Pan, X. Yang and D. F. Zhang, “Chemical Nature of Phytic Acid Conversion Coating on AZ61 Magnesium Alloy,” Applied Surface Science, Vol. 255, No. 20, 2009, pp. 8363-8371. http://dx.doi.org/10.1016/j.apsusc.2009.05.089

[23] M. L. Moraes, O. N. Oliveira, U. P. Rodrigues and M. Ferreira, "Phytase Immobilization on Modified Electrodes for Amperometric Biosensing," Sensors and Actuators B: Chemical, Vol. 131, No. 1, 2008, pp. 210-215. http://dx.doi.org/10.1016/j.snb.2007.11.004

[24] D. Zhang, Q. Guo, C. Bian, J. Zhang, S. Lin and B. Su, "Alterations of Steroid Receptor Coactivator-1 (SRC-1) Immunoreactivities in Specific Brain Regions of Young and Middle-Aged Female Sprague-Dawley Rats,” Brain Research, Vol. 1382, 2011, pp. 88-97. http://dx.doi.org/10.1016/j.brainres.2011.01.024

[25] F. Crea, C. De Stefano, D. Milea and S. Sammartano, "Formation and Stability of Phytate Complexes in Solution," Coordination Chemistry Reviews, Vol. 252, No. 10-11, 2008. pp. 1108-1120. http://dx.doi.org/10.1016/j.ccr.2007.09.008

[26] Q. C. Chen and B. W. Li, "Separation of Phytic Acid and Other Related Inositol Phosphates by High-Performance Ion Chromatography and Its Applications," Journal of Chromatography A, Vol. 1018, No. 1, 2003, pp. 41-52. http://dx.doi.org/10.1016/j.chroma.2003.08.040

[27] J. Torres, S. Dominguez, M. F. Cerda, G. Obal, A. Mederos, R. F. Irvine, A. Diaz and C. Kremer, "Solution Behaviour of Myo-Inositol Hexakisphosphate in the Presence of Multivalent Cations. Prediction of a Neutral Pentainagnesium Species under Cytosolic/Nuclear Conditions,” Journal of Inorganic Biochemistry, Vol. 99, No. 3, 2005, pp. 828-840. http://dx.doi.org/10.1016/j.jinorgbio.2004.12.011

[28] F. Witte, F. Feyerabend, P. Maier, J. Fischer, M. Stormer, C. Blawert, W. Dietzel and N. Hort, "Biodegradable Magnesium-Hydroxyapatite Metal Matrix Composites,”
Biomaterials, Vol. 28, No. 13, 2007, pp. 2163-2174.

[29] X. N. Gu, Y. F. Zheng, S. P. Zhong, T. F. Xi, J. Q. Wang and W. H. Wang, "Corrosion of, and Cellular Responses to Mg-Zn-Ca Bulk Metallic Glasses,” Biomaterials, Vol. 31, No. 6, 2010, pp. 1093-1103. http://dx.doi.org/10.1016/j.biomaterials.2009.11.015

[30] R. O. Hynes, "Integrins: Versatility, Modulation, and Signaling in Cell Adhesion,” Cell, Vol. 69, No. 1, 1992, pp. 11-25.

[31] C. M. Serre, M. Papillard, P. Chavassieux, J. C. Voegel and G. Boivin, "Influence of Magnesium Substitution on a Collagen-Apatite Biomaterial on the Production of a Calcifying Matrix by Human Osteoblasts," Journal of Biomedical Materials Research, Vol. 42, No. 4, 1998, pp. 626-633. http://dx.doi.org/10.1002/(SICI)1097-4636(19981215)42: 4<626::AID-JBM20>3.0.CO;2-S

[32] M. H. Santos, L. G. D. Heneine and H. S. Mansur, "Synthesis and Characterization of Calcium Phosphate/Collagen Biocomposites Doped with $\mathrm{Zn}^{2+}$, "Materials Science and Engineering: C, Vol. 28, No. 4, 2008, pp. 563-571. http://dx.doi.org/10.1016/j.msec.2007.07.002

[33] F. A. Leone, P. Ciancaglini and J. M. Pizauro, "Effect of Calcium Ions on Rat Osseous Plate Alkaline Phosphatase Activity,” Journal of Inorganic Biochemistry, Vol. 68, No. 2, 1997, pp. 123-127. http://dx.doi.org/10.1016/S0162-0134(97)00047-0

[34] A. Grandjean-Laquerrier, P. Laquerriere, E. Jallot, J. M. Nedelec, M. Guenounou, D. Laurent-Maquin and T. M. Phillips, "Influence of the Zinc Concentration of Sol-Gel Derived Zinc Substituted Hydroxyapatite on Cytokine Production by Human Monocytes in Vitro,” Biomaterials, Vol. 27, No. 17, 2006, pp. 3195-3200.

http://dx.doi.org/10.1016/j.biomaterials.2006.01.024

[35] N. Veiga, J. Torres, S. Dominguez, A. Mederos, R. F. Irvine, A. Diaz and C. Kremer, "The Behaviour of MyoInositol Hexakisphosphate in the Presence of Magnesium(II) and Calcium(II): Protein-Free Soluble InsP6 Is Limited to 49 microM under Cytosolic/Nuclear Conditions," Journal of Inorganic Biochemistry, Vol. 100, No. 11, 2006, pp. 1800-1810. http://dx.doi.org/10.1016/j.jinorgbio.2006.06.016

[36] W. Paul and C. P. Sharma, "Effect of Calcium, Zinc and Magnesium on the Attachment and Spreading of Osteoblast Like Cells onto Ceramic Matrices,” Journal of Materials Science: Materials in Medicine, Vol. 18, No. 5, 2007, pp. 699-703. http://dx.doi.org/10.1007/s10856-006-0005-1

[37] Z. J. Li, X. N. Gu, S. Q. Lou and Y. F. Zheng, “The Development of Binary Mg-Ca Alloys for Use as Biodegradable Materials within Bone,” Biomaterials, Vol. 29, No. 10, 2008, pp. 1329-1344.

http://dx.doi.org/10.1016/j.biomaterials.2007.12.021 